\title{
A Text in the Communicative Dimension: The Relationship between the Open and Closed Text in the Context of Umberto Eco's Ideas
}

\author{
Asst. Prof. Olga Gilyazova \\ Ural Federal University \\ Center for the Development of Universal Competencies \\ olga_gilyazova@mail.ru
}

\begin{abstract}
The article addresses the relationship between open and closed texts. The aim of the study is to analyze the specifics of relationship between the open and closed text in the general context of communication between the author and the reader. While supporting mainly U. Eco's concept in our article, we furnish it with the analysis of four approaches of openness/closedness, which we have singled out. Openness/closedness is conceptualized, firstly: as an ontological perspective of the opposition between the communication parameters: The text-as-process and text-as-outcome; secondly, as interpretation procedures that are common for the articulation of all texts, regardless of their form and contents; thirdly, as the ontological and technological potential of works' physical unfinishedness that invite the recipient to co-authorship (for example, 'the work-in-movement' and hypertext); fourthly, as the ability of a text to provoke multiple or unambiguous interpretations. We also demonstrate that the way of text's functioning is determined not only by the addressee's attitude to it, but text itself, in return, stimulates this attitude, predisposing to it by its specificity (as informative or artistic, kitsch or art, hypertext or linear text, digital or analog). However, as we explain in the conclusion, the dialectic of openness/closedness can affect the distinctness of these dichotomies: The text can use its openness manipulatively, which turns it into a closed text.
\end{abstract}

Keywords: Author and reader, code, communication, hypertext, interpretation.

\section{İletişim Boyutunda Metin: Umberto Eco'nun Fikirleri Bağlamında Açık ve Kapalı Metin Arasındaki İlişki}

Öz

Adı geçen makale, açık ve kapalı metinler arasındaki ilişkiye değinmektedir. Çalışmanın amacı, yazar ve okuyucu arasındaki genel iletişim bağlamında açı ve kapalı metin arasındaki ilişkinin özelliklerini incelemektir. Makalemizde esas olarak U. Eco'nun konseptini desteklerken, onu, seçtiğimiz dört açıklı/kapalılık yaklaşımının analiziyle sunuyoruz. Açıklık/kapalılık yaklaşımları şu biçimlerde kavramsal bir vücuda bürünür: bunlardan ilki iletişim parametreleri arasındaki karşıtlığın ontolojik bir perspektifi olarak: metin bir süreçtir ve metin bir sonuçtur; ikinci olarak, biçim ve içeriklerine bakılmaksızın tüm metinlerin eklemlenmesi için ortak olan yorumlama prosedürleri olarak; üçüncü olarak, 
alıcıyı ortak yazarlığa davet eden eserlerin fiziksel bitmemişliğinin ontolojik ve teknolojik potansiyeli olarak (örnek olarak 'hareket hainde çalışma' ve hipermetin); dördüncüsü, bir metnin birden çok veya kesin yorumlamaya neden olma yeteneği olarak. Bunun haricinde metnin işlevsellik durumu onun sadece okuyucusu üzerindeki etkileşimi ile değerlendirilmeyip, metnin de kendi özelliğini ortaya koyarak bu etkileşimi uyardığı ve yatkınlık sergilediği de göz önüne serilmektedir (tarz olarak bilgilendirici ya da sanat ağırlıklı, kitsch veya yaratıcı sanatsal, hipermetin veya doğrusal yazım biçiminde olabilir, dijital veya analog). Sonuç itibariyle toparlayacak olursak açıklık/kapalılık yaklaşımları bu ikilemlerin netliğine zarar verebilmektedir: metin kendi açıklığını manipüle edici nitelikte kullanabilmekte ve nihai olarak da kapalı biçime dönüşebilmektedir.

Anahtar Kelimeler: Yazar ve okuyucu, kodlar, iletişim, hiper metin, yorumlama. 


\section{INTRODUCTION}

The present-day situation in text studies is characterized by refocusing from the 'narrow,' synchronous perception of the text as an autonomous static entity to its 'broader,' diachronous understanding where it is seen as a dynamic system characterized by active interaction of all the communication elements.

Yet, according to a number of renowned scholars, we deal with not just the narrow and the broad perception of the text, but with its two interrelated forms (or stages of existence): The text as process and the text as outcome. This dichotomy becomes stronger through the differentiation of the texts depending on the potential of their perception and understanding. If in the first case the extent of variability of text interpretation reaches its maximum, in the other case it stays at its minimum or is nullified. By analogy with the biological concepts of genotype and phenotype, J. Kristeva defines these two forms of text as the genotext and the phenotext; R. Barthes counterposes them as the Text and the work or writerly and readerly texts; $U$. Eco refers to them as open and closed texts.

The purpose of our work is to outline possible approaches that emerge when thinking about the specifics of the relationship between the open and closed text in the context of the author and reader/audience communication. To do this, we will generally follow U. Eco's concept, as it is distinguished not only by its depth, but also by its well-reasoned approach. We use U. Eco's main theoretical works as a reference source $(1979,1989,1990,1992,1996$, 2000, 2013). But following the path beaten by U. Eco, we had no intention of retelling his views (which he, as a non-dogmatic scientist, revised at different periods of his life), rather, they will serve as a context for our reflection.

\section{THE AUTHOR AND THE READER}

The dilemma between open and closed texts is most clearly seen in the opposition between 'the clean sheet' open for uncontrolled filling where limits are set by the author's will and the printed book claiming completeness and invariability. The 'Gutenberg era' (for Herbert Marshall McLuhan) or, more generally, the 'age of mechanical reproduction' (for Walter Bendix Schönflies Benjamin) ushered in differentiation and opposition between two stages in the life of any text:

1) the text as writing, i.e. the text during its maturation controlled by the author (the open text);

2) the text as an object of mass reading (consumption), the production and distribution of which is beyond the author's domain (the closed text). However, the Gutenberg period creates the conditions that undermine the very principle of mass production with its inherent commitment to invariability, authority and completeness. "The custom to republish books means for the author [...] a true encouragement for rewriting" (Boie, 1999, s. 176). Quite often, it means additions and rewriting alterations as we can see in republished poems by Georg Trakl or in Orlando Furioso by Ludovico Ariosto, and in The Messiah by Friedrich Gottlieb Klopstock, and in Essays by Michel Eyquem de Montaigne. For the above poets, the printed book was seen as mere preservation of the intermediate stage of the open existence of the incompletable (during the author's lifetime) text. It is the process of writing, artistic freedom and the author's power over the text that make it impossible for the ontologically closed text to remain static in its completeness. However, when given a form, the author's conception acquires certain autonomy from its creator. The text in its printed form starts 
developing the story of its reading, which cannot be controlled even by the author. The above problem was encountered by Lev Tolstoy, when during his spiritual transformation he wanted to revise and rewrite some of his former works. "The text has an impact on the history not through what is written in it, but through what and when was read in it and through its reader." (Etkind, 2001, s. 429). There is no text without the author; on the other hand, the text cannot exist as a text without the reader.

The literary work is not a stand-alone object that always offers the same view to every viewer. It is not a monument that monologically reveals its timeless essence. Rather, it is like a score based on the ever-renewed resonance of the reading, which liberates the text from the matter of words and brings it to a topical existence (Jauß, 1979, p. 162).

The above fact is well explained by reception aesthetics that developed and expanded the ideas of Hans-Georg Gadamer who was famous for his philosophical hermeneutics as well as the ideas of philosophers-phenomenologists: Martin Heidegger, Nicolai Hartmann, Roman Ingarden. Although American reader-response criticism and the Buffalo School overemphasized the reader's role, the leading representatives of the German School of reception aesthetics (Constance School), Hans Robert Jauss and Wolfgang Iser, were able to avoid such radicalism.

Not only the text as the closed conditional reality requires its 'opening' through the process of perception, but also the text that is being created, i.e. while it is still open, inevitably turns to already completed texts-outcomes. All of this helps to perceive the text as an intertext. Intertextuality as a term was first introduced by Julia Kristeva who based her theory on M. Bakhtin's concept of dialogism. Text in both its communicative dimensions (in the process of its creation and in the process of its perception) is forced to function as an intertext. "Every word (every sign) of the text leads beyond it. Any understanding is a correlation of this text with other texts" (Bakhtin, 1979, s. 364).

The maturation of understanding the text as the intertext goes hand in hand with the refocusing of contemporary text studies from the Author ${ }^{1}$ to the reader who remained on the fringes of humanitaristics till the 1960s. As R. Barthes (1977) expresses it: "Classic criticism has never paid any attention to the reader; for it, the writer is the only person in literature. [...] [T] he birth of the reader must be at the cost of the death of the Author" (p. 148).

As noted by A. R. Usmanova, such marginality of the reader resulted from the dominating concept of God as the Author of creation. Throughout the centuries, this concept

Directly or indirectly inspired traditional historiography, literature studies, art and other sciences prone to the cult of creative and great personalities [...]. The position of the demiurge and the concept of the invisible center, due to which the One (the universe) acquires certain wholeness and meaningfulness, were not instantly eliminated by Nietzsche's pronouncement that 'God is dead': We learned the lessons of structuralism well enough to understand that the center and the place of God are the effect of the structure. Therefore, the cult of the Author quite logically was superseded by the cult of the Reader the new Dieu caché, who provides words with the meaning, gives names to things and puts the world in order by moving his eyes (Usmanova, 2000, ss. 132-133).

${ }_{1}$ Peculiar culmination of strengthening the figure of the Author was the 'biographical' method, which was proposed by a famous literary critic Charles Sainte-Beuve in the XIX century. 
This explains the prioritization of the reader's preferences defining, for Jacques Derrida and Richard Rorty, the meaning of the text. However, researchers often prefer to deal not with real readers, but with their image in the text. Concepts are introduced: The 'Model Reader' (U. Eco), 'intended reader' (E. Wolff, H. Link, G. Grimm), 'informed reader' (S. Fish), 'implied reader' (Wayne C. Booth, W. Iser), 'superreader' (M. Riffaterre) (see, for example: Slabukho, 2006, s. 80; Schmid, 2013). These terms characterize "function of the work" (Schmid, 2013) ("as a presumed addressee" (ibid.) and "as an image of the ideal recipient" (ibid.)), and not a real reader as a flesh-and-blood person.

Such attention to the ideal reader and their varieties is often construed as almost complete indifference to the sociocultural context of perception and, therefore, to the empirical reader. However, the present-day plethora of psychoanalytical, feminist and sociological theories of perception shows that the actual subject of reception is not neglected by contemporary scholars.

The author is not detached from the text completely: Although he is no longer seen as the creator, he is declared as a function essential for discourse. 'The author's name' is different from a proper name. 'The author's name' is pronounced by M. Foucault as an equivalent of the description that makes it possible to group together a number of texts and thus differentiate them from other texts belonging to another author or tradition (see: Foucault, 1996, pp. 22-25). However, the modern literary studies are characterized by the presence of the various concepts of 'resurrections' of the author that have occurred since Roland Barthes's authorial death sentence in 1968 (see: Garayalde, 2018).

\section{OPEN AND CLOSED TEXTS}

Roland Barthes makes a distinction between two kinds of text: the writerly and readerly or the Text and the work. Readerly and writerly texts - are terms R. Barthes employs to investigate ways of reading, like the passive/ active ways of interacting with a text. Readerly or closed texts, following U. Eco's terminology, are texts that make no requirement of the readers to 'produce' or 'write' their own meanings. These are texts, which are initially meant to produce the author's intended impression on the reader: Through thoroughly designed effects, they generate the expectation that is justified during the narration. Although it is justified, it may often be not proved true: Omissions and 'unmet expectation' of the reader/ viewer are frequent ploys of the code aimed to hold the attention of addressees, keeping them in suspense, making them stay interested right to the very end. This ploy is used by many pulp fiction books gaining popularity due to their entertaining and intriguing features backed up by unpredictability of the plot however being often disposed of after first reading. On the other end of the spectrum there are texts that use the intertextual competence of the reader against himself: They create innovative techniques, which are welcomed in the treasure-house of intertextuality; however, when used by imitators, they are degraded and turn into platitudes.

Yet, one and the same text can function at both ends of the spectrum, gaining interest both of the sophisticated reader and the mass reader. This feature is inherent in the best examples of postmodern literature: novels by U. Eco, V. O. Pelevin, B. Akunin, Perfume: The Story of a Murderer by P. Süskind, etc. We are talking about texts where 'dual coding' (Eco, 2013, ss. 29-32) stems from the presence of two levels.

SEFAD, 2021; (45): 191-208 
The intertextual level of the text carries signs, discourses and meanings, which address the non-mainstream readers or humanities scholars who are able to understand and construe them. The narrative layer is aimed at the mainstream, unexperienced reader who is interested in the plot, relationships between the leading characters, descriptions, etc. (Fedorov, 2016, s. 550).

As a matter of fact, the tyrannical power of code, whether it rests on the addressee's intertextual competence or counteracts it, seeing it as inappropriate, is inherent, according to U. Eco, in closed texts. However, this power is not able to come to life and be efficient without taking into account the role of the recipient whose cooperation is provided for by open texts. Basically, "the reader as an active beginning of interpretation constitutes a part of the process of text generation" (Kosikov, 2000, s. 15).

To this extent, all texts are actually open texts or, in other words, devices, the generation process of which includes interpretation by the addressee. The above is true even for the texts that cannot deviate from the logic of progression of events, such as 'live on-thespot reports.' The truth of this statement does not override the thesis asserting that the open text is rather a model, an 'ideal type' (following the terminology of M. Weber). As Eco asserts: "So-called open-texts are only the extreme and most provocative exploitation-for poetic purposes - of a principle which rules both the generation and interpretation of texts in general" (Eco, 1979, pp. 4-5).

Texts need involvement of the addressee without whose interpretation no message can be actualized as a text. However, only 'obedient' cooperation determines the closedness of a text. As Cary Campbell (2018) demonstrates in detail, such a closed interpretation often works as kitsch: "Kitsch is made up of devices that are stolen from culture precisely because of their ability to elicit a controlled response in the interpreter" (p. 311), because project of kitsch "is not that of involving the reader in an act of discovery but that of forcing him to register a particular effect (in the belief that therein lies aesthetic pleasure)" (Eco, 1989, p. 183).

Kitsch masquerades as art. "It is this parasitical nature that allows kitsch to be so easily co-opted for ideological and manipulative ends" (Campbell, 2018, p. 311). Of course, it would be naive to think that this manipulative and ideological characteristic of kitsch distinguishes it from art. To this extent, even S. M. Eisenstein's films are closed, as the viewer's creative participation promoted by the film director is used by the latter for sophisticated and astute (which makes it more efficient) manipulation of the mind. So Campbell (2018) is right when he says: “[...] [I]t is the addressee's/learner's personal responsibility to continually address whether their interpretative possibilities are being further opened and expanded, or rather, closed and restrained" (p. 312).

Open texts imply active and, most importantly, free collaboration, encouraging the addressee to produce multiple diversified, though not arbitrary and accidental, interpretations, due to which the text becomes richer and more versatile than the author's conception.

It should be made clear that open texts differ from closed texts not by removal of the author's viewpoint. It is present even in intentionally impersonalized scientific texts. The main distinction involves elimination of authoritarian, categorical and uncontested 
compulsoriness of code, which the author must match, as it represents authoritativeness of requirements of the genre (including scientific), style and content.

It is obvious that imaginative, literary texts are potentially more open than scientific and informative texts notable for their maximum 'transparency', which is achieved through established terminology and using of artificial languages, which help these texts get rid of ambiguity hindering their understanding2. "Any work of art can be looked at as a message to be decoded by an addressee. But unlike most messages, instead of aiming at transmitting a univocal message, the work of art succeeds precisely insofar as it appears ambiguous and open-ended" (Eco, 1989, p. 195). Openness also disagrees with the texts that perform prescriptive and commissive (with reference to commitments and obligations) functions: regulatory acts, guidelines, promises, resolutions, orders, oaths, etc. Such texts imply not only fulfilment, but also the possibility to assess precisely the liability for deviation from the requirements specified in them. Anyway, if driven to extremity, the thought about openness of the text can lead to the idea that inkblots represent the most open texts: What a scope for interpretation! It has almost no limits except for imagination and free associations (which also tend to have limitations used by psychologists in Rorschach tests). However, the experiments of Dadaists, paintings of abstractionists, suprematic Black Square of Malevich, glossolalia in the Khlysty sect, 'mind-bending' language of futurists clearly show us that the problem is not as simple. In U. Eco's opinion, by announcing the Informal we do not adjudge the Form to death; on the contrary, we encourage the maturation of understanding the form as a field of possibility. "[...] [T] he dialectics between the work itself and the 'openness' of the 'readings' it invites " (Eco, 1989, p. 100) does not eliminate the necessity to consider the fact that "a work of art can be open only insofar as it remains a work; beyond a certain boundary, it becomes mere noise" (ibid). Some representatives of postmodernist literature and theory try to cross the boundary, having no concern that "plentitudes, pile-ups of various meanings, interpretations, and viewpoints are fraught with the author's as well as the viewer's, the reader's and the listener's slipping into insanity, and at some moment the insanity becomes the inherent value" (Tulchinsky, 2001, s. 15).

\section{INTERPRETATION AND OVERINTERPRETATION}

The problem of interpretation - one of the most important in Eco's work - is a reflection of the dialectic between the opening and the closing of a text. Although U. Eco was among the first who opened the prospect of the reader's participation in generation of textual meaning, it was he, "when this tempting idea mesmerized critics" (Usmanova, 2000, s. 145), who declared that "my readers mainly focused on the 'open' side of the whole business, underestimating the fact that the open-ended reading I was supporting was an activity elicited by (and aiming at interpreting) a work." (Eco, 1992, p. 143).

The so-called 'hyperinterpretation' was a symptom of the dangerous trend, the foundation for which was laid by him in his early work Opera aperta (1962) (English translation: The Open Work (1989)). Thus, he had to fight against that trend in his later work The Limits of Interpretation (1990) and the collection of Tanner Lectures Eco presented at

${ }^{2}$ In scientific texts, the accuracy of communicated information is of paramount importance; it is achieved through
the minimization of technical and semantic noises as well as their consequences. On the other hand, in literary texts,
even noise can contain additional information. For example, darkened with time painting by Rembrandt - The
Shooting Company of Frans Banning Cocq and Willem van Ruytenburch commonly referred to as The Night Watch
(though initially, the artist portrayed the action taking the place during daytime). (Gilyazova, 2020, p. 285, note). SEFAD, 2021; (45): 191-208 
Cambridge University in 1990 (1992). U. Eco argued against "the illusion that the reader can read the text in the way he wants, without any restrictions imposed by rules of reading and without taking into account the text intention, not to mention the 'immanent' meaning" (Usmanova, 2000, p. 146). How can one get around Scylla and Charybdis: the readeroriented paradigm (David Cooper, Ronald Laing, and Felix Guattari) and the non-readeroriented paradigm? Eco writes that he decided to consider a third option.

Thus, Eco (1990, pp. 50-51) distinguishes among three types of intentions:

1. The intentio auctoris: what the empirical author intends to say;

2. The intentio operis: what the text wants to say;

3. The intentio lectoris: what the readers make the text say with reference to their own system of expectations, wishes, drives, beliefs, stereotypes, etc.

Following deconstructionists, the New Critics, formalists and structuralists, Eco does not admit that interpretation can be linked to the intentio auctoris.

This can be seen as a response to misguided approaches to the school course of literature, when it is focused on studying biographies of famous writers and on delving into the question: 'What did the author want to say by his writing?' A good objection to this question can be found in L. N. Tolstoy's letter to N. N. Strakhov, written on April 26, 1876: "If I wanted to say in words everything I intended to express through the novel [Anna Karenina], I would have to write a novel - that very novel I have written, but once more." (quoted after Tolstoy, 1939).

If the intentio auctoris is not instrumental for a literary text, is it also not essential for other texts? In fact, the speech act theory assumes that the illocutionary force of an utterance directly depends on the speaker's intention. It is especially important to identify the intention of the sender when the ontological status of the ongoing situation is not clear: For example, the cry 'Fire!' at the Khromaya Loshad (Perm, Russia, 2009) nightclub was initially perceived as part of the entertainment program (i.e. as the conditional reality) rather than a danger warning (the actual reality) and thus, to a large extent, exacerbated the tragic consequences.

As for the intentio lectoris, according to Eco, the text is not only a generative matrix, but also a system of restrictions. Although open texts, as opposed to closed ones, give the reader quite substantial freedom of action, the reader should remember that his interpretation movement "may not be comparable to a one-way street but to a network of multilane freeways along which one can travel in more than one direction; but despite this some roads will nevertheless remain dead ends. There are things that cannot be done (or said)." (Eco, 2000, p. 53).

Undoubtedly, the empirical reader may not want to follow the directions readily available in the text and may want to go his own way. The problem is to establish point in which freedom of interpretation degenerates into aberrant decoding or, in other words, this interpretation turns into the use of text. (Eco, 1990). Eco sees them as opposition notions.

For this reason, "between a quasi-irrelevant intentio auctoris and a potentially unbridled intentio lectoris, Eco postulates the presence of a channeling intentio operis, a 
system of textual guard-rails that restrain the meanings that may be reasonably attributed to the text itself." (Pisanty, 2015).

What is the intention of the text? How can we separate righteous interpretations from those that are not righteous? This question is currently central for many critics and, as admitted by William O. Hendricks, Elena Esposito and Valentina Pisanty, Eco does not give any all-encompassing answer. Verification, in his opinion, must be based on conformity to the literal meaning of the text. This negativistic approach is helpful in handling false and invented interpretations that can be ignored, but it does not resolve the issue of defining the 'legality' degree of the 'righteous' interpretations.

In my opinion, this approach bridles the interpreter's imagination and is useful in work of translators ${ }^{3}$, literary critics, etc. Yet, is it highly important for usual readers who do not have to comply with the requirements of corporate ethics? Should the creative urge of readers (including scientists) be suppressed, even though it drifts them away from the stimulus text? Following this approach, we should accuse Freud's concept of Oedipus complex of representing an example of inadequate (excessive) interpretation of Oedipus Rex by Sophocles.

This problem has not only a purely theoretical aspect, but also a practical one. Eco himself encountered examples of interpretation, which he rejected as "noncompliant with the principle of efficiency" (Eco, 2013, s. 51). We are talking about the essay The Name of the Rose written by Yelena Kostyukovich (1982), a Russian translator of U. Eco's works. U. Eco found irrelevance in numerous allusions encountered by the translator in his novel, though, in his opinion, the translation itself was 'exemplary's.

We observe a contradiction: U. Eco, as a theorist, neglected the value of an empirical author, denying the relevance of his intentions, but being an empirical author himself, he controlled the translation and adaptation of his books very scrupulously, i.e. violated, when it was convenient, his own regulations.

Thus, we can state that even the semiotician who (especially towards the end of his career) postulates that there are limits of text interpretation, even though they do not depend on interference of the author's authority, does not escape the controversy and temptation to intervene in public debates to restore some of the authority lost when the author was adjudged to death by R. Barthes.

In this case, we tend to share the view of Valentina Pisanty (2015), "the meaning, or rather meanings of a text derive from the tensive and sometimes variable interaction between the three intentions, none of which may be completely put aside to the advantage of the other two."

\footnotetext{
${ }^{3}$ On the other hand, the situation with translators is also not clear-cut and conclusive: For example, as is known, in Sweden Astrid Lindgren's Karlsson-on-the-Roof is not as popular as in Russia. Apparently, this book owes its success with Russian readers (frequently turning to it as a source of popular quotes) to the translation done by Lilianna Lungina who imparted liveliness to the spiritless original story.

${ }^{4}$ But not everyone shares his opinion. The Russian-speaking readers of The Name of the Rose should have been inspired by the Middle Ages' spirit. For this purpose, Russian Church Slavonic is used as a functional analogue of Latin in Kostyukovich's translation. But some Latin phrases remained, as a result a very strange mixture of Russian Church Slavonic, modern Russian and Latin languages turned out. It seemed that the Catholic monk Adson (originally - Adso) wrote both in Latin and in Russian Church Slavonic. This is an obvious flaw of translation, a clear violation of the semantic level of the text (see: Ryzhenkova, 2003).
} 
It can be noted that from the perspective of typology of reception approaches, which was offered by J. Staiger (1992, pp. 35-47), U. Eco's concept can be seen (along with theories of R. Barthes, J. Culler, S. Fish, W. Iser, M. Riffaterre and G. Genette) as the so-called textualactivated approach. In this approach, it is the text that sets game rules for the reader who is guided by textual conventions. The text has a 'strategy' that models the 'reader response' in a certain way.

The discovery and justification of this fact allowed the critics of the semiotic and receptive-aesthetic paradigms 'to reconcile' the idea of a potential plurality of meanings of the text with the idea of having a spectrum of stable meanings in it. But it required a certain distancing from the factor of the real context of reading: the problem of the reception was almost entirely transferred to the plane of studying the reader as an ideal abstraction, modeled by the text (Turysheva, 2010, s. 308).

Thus, the text-activated approach allows researchers to avoid the extremes of the reader-activated approach that brings the reader's activity to the forefront. But this textually activated approach does not fully take into account the achievements of the contextactivated approach that focuses on the role of the cultural and historical context of the reception. This context, in its turn, forms readers' 'horizon of expectations' (see: Jauss, 1982, p. 24). Moreover, "each culture in each paradigm has a 'horizon of expectations'- a set of assumptions which will contribute to the production of certain kinds of readings" (Green \& LeBihan, 2003, p. 211).

\section{FOUR MAIN APPROACHES OF OPENNESS/CLOSEDNESS}

Thus, works by contemporary scholars offer several definitions of the 'openness/closedness' concept with regard to texts.

\section{First approach}

[...] [I]t is possible to apply the open-closed distinction to texts by seeing it in terms of the issue of self-sufficiency or autonomy. A closed text is one that is regarded as autonomous, in the sense that it is separable from the author, the readers, and the social and cultural context in which text production and reception take place. An open text, inversely, is one that is conceived as a component part of the communicative situation. (Hendricks, 1981, p. 362).

Here we have the opposition between the open text "as an unfinished live text taken at the moment of its direct embeddedness in the act of communication" (Kasavin, 2006, s. 13) and the closed text, "which is already alienated from the author by spatial, temporal and other indexical parameters" (ibid), though their interconnectedness is still in place.

This approach offers the differentiation between "the structurally closed text-as-aproduct and functionally open text-as-a-process" (Makarov, 2003, ss. 88-89). It entails other opposition criteria: functionality - structurality, process - product, dynamic - static and reality virtuality. This approach prioritizes communicative and ontological parameters. This approach completely disregards the content-related aspect of the texts, thus significantly limiting its heuristic capabilities.

And another limitation of this approach: it does not correspond to the new communication paradigm that is taking shape with the advent of digital ICTs, which cancel this opposition between open and closed texts. It is digitalization that expands the 
possibilities of ontological openness (initially limited by the above-described dilemma between 'the clean sheet' and the printed book (or any physically immutable, preserved cultural artifact) that 'works-in-movement' artificially try to overcome), sometimes allowing it to acquire a truly artistic character rather than a technological one. As a result, the former viewer (and consumer) of author's texts is replaced by the figure of an 'active user' who constructs an object by his own actions. A number of researchers describe this process through the concept of 'prosumerism' (producer + consumer), as opposed to the concept of 'consumerism.' (Toffler, 1980; Tapscott, 1995).

If before digitalization this combination of the roles of content producer/consumer was rather experimental (Marcel Duchamp and the Dadaists; members of the Fluxus and conceptual artists, as well as composers - Steve Reich, John Cage, Terry Riley and Philip Glass; theater directors - Peter Brook and Antonin Artaud, etc.), then in recent years, thanks to the technological boom and the spread of the Internet (especially Web 2.0), it has become one of the fundamental algorithms of culture and has entered everyday life.

Of course, even in cyberculture ${ }^{5}$, the concept of authorship will not disappear (it is necessary, at least in the legal sense), but the dichotomy of the author/reader-viewer, sender/recipient, producer/consumer loses its clarity.

\section{Second approach}

The broadest (and the least concise) definition, which was the trigger the formulation of the interpretive cooperation principle, can be found in Eco's thesis: It is "the halo of openness that radiates out of every proposition [...] and that accompanies all human communication" (Eco, 1989, p. 30).

In this sense, all texts (not only texts that display an aesthetic function), to some extent, are open, as their openness stems from the fact that "insofar as all texts are structured in such a way as to give their users some leeway for interpretative maneuvering, which may vary according to the type of text" (Pisanty, 2015).

However, this approach to understanding of openness converts the problem of the difference between the texts to the problem of the measure rather than the essence. "The quantitative distinction between open and closed is ultimately unsatisfactory" (Hendricks, 1981, p. 370).

\section{Third approach}

The intentionally narrowed-down interpretation of openness can be found in U. Eco's studies of poetics of avant-garde works, which he calls works-in-movement.

They are unique in that the author relies on the readers/audience and intentionally leaves his work physically unfinished. Music by Karlheinz Stockhausen, Henri Pousseur, Luciano Berio as well as Alexander Calder's mobiles (kinetic sculptures powered by motors or air currents) and Raymond Queneau's A Hundred Thousand Billion Poems and Stephane Mallarme's Un coup de dés can serve as an example. The dynamic nature of such texts, which is manifested in potential incompleteness, in physical unfinishedness, i.e. openness in the expression plane, also provides for openness in the content plane, inviting to create the work together with the author.

${ }^{5}$ As Carlos Alberto Scoları (2009) rightly writes: “The new digital communication products also challenge Walter Benjamin's classical opposition between original work and technical reproduction" (p. 958) 
The drawback of this approach is that it focuses (though, unlike the first approach, is not limited to) on the ontological aspect of openness. Inefficiency of this understanding of openness (unless it is supported by the artistic measurement of openness as richness of the code) is well demonstrated by hypertexts.

The hypertext is not so much artistic as technological manifestation of 'work-inmovement.' The nearly non-physical mobility (on the digital medium) of the hypertext demonstrates blurring of the line between closed and open texts, the author and the reader; without removal of the author it challenges the authorship principle, disabling its singularity, integrity, authority, credibility and autonomy. The syntagmatic non-linearity of the spatial structure of the hypertext as well as paradigmatic non-hierarchy of its conceptual blocks provide the reader with 'travel' possibilities available only in closed texts, while intrusion into the text fabric can be offered only by open texts.

Structural possibilities of an easily modulated digital medium offer its user benefits of the non-linear text combining characteristics of ontologically open and closed texts, while being free of their limitations, the fight with which can be traced in modernist and postmodernist literature. For example, in The French Lieutenant's Woman by John Robert Fowles, in Hopscotch by Julio Cortázar, The Infinite Deadlock by Dmitry Galkovsky, in Dictionary of the Khazars and The Glass Snail by Milorad Pavić. Encountering the obstacle represented by its initially linear arrangement, the standard printed book does not reach the level of a computer hypertext.

The hypertext in its best artistic practices (for example, interactive projects - B. Akunin's literary games) can be considered as almost visible implementation of Borges' Library of Babel or even The Garden of Forking Paths.

In the meantime, by no means all hypertexts are aimed to activate creativity of the readers and to turn them into co-authors; on the contrary, in some cases they represent the communication (for example, the definition of each term is recorded in an encyclopedia) that can cause a decrease in the reader's contribution to the finalizing meaning of the text by luring the reader into what can be deemed, from the reader-response criticism perspective, 'closed' or passive enjoyment.

Ultimately, the creative freedom of the interactive reader of hypertexts should not be overestimated: "The computer offers the reader a finite set of template episodes, 'text chunks.' Here, the usual alphabet is very efficient. At the same time, the computer $[\ldots]$ inspires creative exploration. However, on its own, it is not able to satisfy the intellectual needs it inspires." (Mankovskaya, 2000, s. 319).

Not without reason, U. Eco shows that usual books have their advantage over the hypertext.

A hypertextual and interactive novel allows us to practice freedom and creativity [...]. But the written War and Peace does not confront us with the unlimited possibilities of Freedom, but with the severe law of Necessity. In order to be free persons we also need to learn this lesson about Life and Death, and only books can still provide us with such a wisdom (Eco, 1996).

Thus, the existence of ontologically technological openness, which is not enriched with artistic openness, does not turn a hypertext into genuine 'work-in-movement', at least, 
in the meaning assigned to it by U. Eco. But one should not neglect the ontological perspective of openness as such. And although U. Eco, as the heir of the analogue era, was highly skeptical about the artistic potential of ontological openness manifested by the arrival of 'digital,' it is hardly worth getting infected with this skepticism from him. The works-inmovement that he analyzed are the intersection of ontological and artistic openness. An intersection that was done without the mediation of digital technologies. But this fact does not mean that such mediation will not allow to achieve the success, on a par with the artistic achievements of the analogue era.

\section{Fourth approach}

Thus, we have the following concept of openness, which is not limited by the ontological nature of the text, as it is in the first or third approach, and is not excessively broad, as it is in the second approach: In contrast to the third approach, fourth openness is carried out even when "a work is provided with a complete, canonical, fully-structured form" (Pisanty, 2015) and in contrast to the second approach, this openness is not satisfied with the process of interpretation as such, but requires its diversity. If according to the second approach, all texts are open, then according to the fourth approach, this privilege belongs only to exclusive texts.

However, this approach also suggests a quantitative rather than essential difference: "an open text would be one that offers more points at which inferences have to be drawn or one in which a greater number or range of inferences can be drawn" (Hendricks, 1981, p. 369).

It is justified in many respects: While supporting open texts with examples, Eco refers to the works that, due to the richness of their code, invite multiple interpretations: Kafka's novels offering no 'clue' for their interpretation; B. Brecht's plays that "makes it possible to unveil and expose the conditional nature of the existing social and political actual reality, its mythological nature (following Barthes' theory)" (Gilyazova, 2019, p. 18); Joyce's works, especially Finnegans Wake, where sophisticated puns and portmanteau words provoke polyvalent 'interpretations' of each sentence.

In their turn, closed texts (U. Eco uses Ian Fleming's novels about James Bond and Superman comic strips as examples) cannot support such diversity of interpretations.

Thus, "a text or sign system is understood as 'closed' if it elicits univocal meanings: expecting a predetermined response from a generic/average reader. A text is 'open' when it fosters a plurality of interpretative possibilities that actively engage the 'existential credentials' of the interpreter" (Campbell, 2018, p. 305).

Yet, open and closed texts differ not only and not so much in diversity of righteous and non-random (this is important!) interpretations encouraged by them, but also in specificity of these interpretations. Speaking of the above examples, it may seem that Eco's differentiation between the open and closed text resembles the divide traditionally established between 'high' and 'low' literature. To some extent, it is true. However, it is the specificity of interpretations that makes this extrinsically apparent differentiation so complicated.

As we have noted earlier in this article, the functions of the code authorizing dispositions of the 'Model Reader' are of primary importance. Closed works represent the 
texts that are intended to be interpreted unambiguously by causing the pre-set responses through using the available effects. In this sense, they are rigid texts, which are eager to be read, "pulling the reader along a predetermined path" (Eco, 1979, p. 8) of interpretation. Then, it is clear why "Eco regards literary works produced in conformity with the medieval theory of allegory, which posited four levels of interpretation, as being closed." (Hendricks, 1981, p. 369).

It also explains why we perceive S. M. Eisenstein's films (and B. Brecht's plays) as closed, though they propagate "the method of the coming-into-being of an image (as distinct from static, representational depiction)" (Eisenstein, 2010, p. 156), which can be correlated with openness in the artistic sense. S. M. Eisenstein and B. Brecht use the artistic openness of their texts to fight against the ideology and to open doors for another one by using manipulations. Their work is much finer and neater than in novels by Fleming who does not hush up his anti-Soviet and anti-communist sentiments, though the intention is the same - to cause the obedient participation of the addressee.

As a kind of summary of this paragraph, we, following Elena Esposito, can state that the main problem of openness/closedness is based on a paradox (which, as befits a paradox, cannot be completely resolved): A text is open if it is constructed by the author in view of an unpredictable multiplicity of interpretations, even those he cannot anticipate. But at the same time, in such a text (aimed at readers with different levels of competence), the very arbitrariness of the interpreter confirms the author's original intention: By demonstrating his freedom, the reader does what the author expects from him. A closed text written with an explicit and unambiguous (ideological, educational) intent often provokes the reader's opposite reaction: The reader does not want to obediently follow the fairway laid for him and thus he opens the text to other readings. Thus, an open text will be closed, because even the most unexpected readers' readings correspond to its intention. And vice versa: a closed text will unwittingly turn out to be open.

As E. Esposito (2013) writes, this paradox's reason is rooted in another paradox:

Ultimately the core of Eco's reconstruction is still the intended meaning of the author's: that original intent which apparently had to be abandoned. Although U. Eco does not take as a reference the sense the author meant, the definition of a text as open or closed relies on who he anticipated as its reader, that is still on his intention. (pp. 173-174).

Eco tries to eliminate this paradox by translating the intentio auctoris into the intentio operis and articulating the dynamics between the Model Author and Model Reader instead of the real author and reader, but this paradox remains relevant.

But this paradox is easily removed thanks to digital ICTs, which, due to their interactivity, stimulate the 'aesthetics of participation.'

Of course, works of art of the analogue era are unthinkable without the interaction of the creator with the material and cannot be actualized without the reception of the reader / viewer who interprets the content. Without the author, there is no text, but without the reader, the text will not take place as a text. In this sense, analog works are also interactive.

But there is a significant difference, identified by the American researcher K. Paul (2003), between the interactivity of traditional texts as interpretative strategies that do not go beyond the mental sphere (going beyond is vandalism, destruction of a work, with the 
exception of work-in-movement), and the interactivity of digital media objects, which allows for the possibility of 'material' transformation.

Thus, although U. Eco tends to neglect the ontological perspective of openness/ closedness, but the emergence of new phenomena associated with the spread of digital ICTs demonstrates that the ontological status of the information carrier is important.

\section{CONCLUSION}

In conclusion it can be noted that we single out two main understandings of openness/closedness: ontological and artistic (they represent scientific novelty of our essay). It should be noted that though these concepts may intersect, they can exist without each other.

It is established that in the plane of content, openness/closedness of the text, following our terminology, corresponds to artistic openness/closedness, while openness/closedness, in the plane of expression, corresponds to ontological (physical) openness/closedness. It is obvious that openness in one plane does not entail automatic openness of the text in the other plane, though texts referred to by U. Eco as 'works-in-movement' are an exception. The identification of the addressee's creative stance (and the specifics of the text predisposing to it) makes us focus on openness/closedness of texts, first of all, which is studied in the plane of content, in contrast and in addition to its studying in the plane of expression.

Thus, based on two concepts - ontological and artistic openness/closedness, we come to the identification of four approaches of openness/closedness.

The first and third approaches orientate on the ontological side of openness. The second approach concentrates on the interpretation procedures required for all types of texts, regardless of their form and content. As a result, the distinction between open texts (more complex for the reader and disruptive for the code) and closed texts (which rely on redundancy to guide the reader's interpretations and reactions) is lost. It is the fourth approach that restores this distinction, which manifests itself in the dichotomies 'art' and 'kitsch,' 'avant-garde' and 'mass culture,' etc.

However, as we have shown in our article, Eco's idea of openness/closedness, in its extreme expression, leads to a paradox: any open text is paradoxically closed because of its openness, and vice versa, a closed text is open because of its closedness. The point is that the theory of U. Eco is trying to cope with two oppositely directed vectors: with the recipient's freedom (openness) and the limits of his interpretation (closedness), with the text as a field of possibilities and the text as a limiter. The tension of these two vectors is the driving force of Eco's creativity and is reflected in the paradoxical and contradictory nature of his works.

Although in our article we tend to follow U. Eco's ideas, we made an attempt to move away from the extremism of his paradoxical approach by demonstrating the primary importance for openness of the text belongs to artistic openness, i.e. flexibility, complexity and richness of code, which provokes active participation of the reader who looks for righteous (though not ambiguous and one-dimensional) text strategies. The difficulty lies in maintenance of the balance: between active, but not exuberant, faithful, but not obedient cooperation of the reader, as the imbalance will turn the work into a closed (even though an artistically closed) text. As we illustrated by using example of B. Brecht and S. M. Eisenstein, 
the artistic significance of the text and its affiliation to the so-called 'high' art do not turn it automatically into an open text.

We also pointed out that digital ICTs pave new ways (which was neglected by W. Eco, apparently due to his commitment to the analogue era and the printed book) for thinking about the relationship between open/closed texts. They demonstrate the importance of understanding openness/closedness not only as an interpretive strategy, but also in an ontological sense.

The dialectics of open and closed texts brings out the significance of the topics addressed in the article and emphasizes the importance of further studies.

Article Information

Ethics Committee Approval:

Informed Consent:

Financial Support:

Conflict of Interest:

Copyrights:
Exempt from the Ethics Committee Decision.

No participant

No financial support from any institution or project.

No conflict of interest.

No material subject to copyright is included. 


\section{BIBLIOGRAPHY}

Bakhtin, M. M. (1979). K metodologii gumanitarnykh nauk [Toward a Methodology for the Human Sciences]. In M. M. Bakhtin (Author), [The] Aesthetics of Verbal Art (ss. 361-373, 409-412). Moscow: Iskusstvo.

Barthes, R. (1977). The Death of the Author. In R. Barthes (Author), Image-Music-Text (pp. 142-148). New York: Noonday.

Boie, B. (1999). Pisatel' i yego rukopisi. In I. I. Dmitrieva (Ed.), Geneticheskaya kritika vo Frantsii: Antologiya (ss. 169-191). Moscow: OGI.

Campbell, C. (2018). Educating Openness: Umberto Eco's Poetics of Openness as a Pedagogical Value. Signs and Society, 6(2), 305-331. DOI: 10.1086/695567. Retrieved from https://www.journals.uchicago.edu/doi/full/10.1086/69556701 September 2020.

Eco, U. (1979). The Role of the Reader: Explorations in the Semiotics of Texts. Bloomington: Indiana University Press.

Eco, U. (1989). The Open Work. Cambridge \& Massachusetts: Harvard University Press.

Eco, U. (1990). The Limits of Interpretation. Bloomington: Indiana University Press.

Eco, U. (1992). Interpretation and Overinterpretation: World, History, Texts. Cambridge: Cambridge University Press.

Eco, U. (1996). From Internet to Gutenberg. A lecture presented by Umberto Eco at Columbia University, November 12. Retrieved from http://www.umbertoeco.com/en/frominternet-to-gutenberg-1996.html. 01 September 2020.

Eco, U. (2000). Kant and the Platypus: Essays on Language and Cognition. New York: Harcourt, Brace \& World.

Eco, U. (2013). Otkroveniya molodogo romanista [Confessions of a Young Novelist] (Aleksandr Klimin, Trans.). Moscow: Corpus.

Eisenstein, S. M. (2010). Laocoön. In Michael Glenny \& Richard Taylor (Eds.), Selected Works, Vol. 2: Towards a Theory of Montage (pp.109-202). London \& New York: Tauris \& Co Ltd.

Esposito, E. (2013). Limits of Interpretation, Closure of Communication: Umberto Eco and Niklas Luhmann Observing Texts. In Anders la Cour \& Andreas PhilippopoulosMihalopoulos (Eds.), Luhmann Observed: Radical Theoretical Encounters (pp. 171-184). Basingstoke: Palgrave Macmillan.

Etkind, A. (2001). Tolkovaniye puteshestviy. Rossiya i Amerika v travelogakh i intertekstakh. Moscow: Novoe literaturnoe obozrenie, 2001.

Fedorov, A. A. (2016). The conception of Umberto Eco's literary art and representation of writer's model 'Umberto Eco - M-author'. Liberal Arts in Russia, 5(6), 543-553. DOI: 10.15643/libartrus-2016.6.1

Foucault, P. M. (1996). What is an Author? The Will to Knowledge. Beyond Knowledge, Power and Sexuality. Moscow: Magisterium-Castle.

Garayalde, N. (2018). The resurrection of the author in current French literary criticism (2008-2011). The case of Pierre Bayard's re-attribution criticism. Revista Co-herencia, 15(29), 251-281. DOI: 10.17230/co-herencia.15.29.10

Gilyazova, O. S. (2019). Theatre and literature: an ontological aspect of their relationship. Antares-Letras e humanidades, 11(24), 3-26. https://doi.org/10.18226/19844921.v11.n24.01 
Gilyazova, O. S. (2020). On the Notion of Text and Its Boundaries in the Context of Semiotics and Communication. Tarih Kultur ve Sanat Arastirmalari Dergisi-Journal of History Culture and Art Research, 9(2), 279-287. https://doi.org/10.7596/taksad.v9i2.2627

Green, K. \& LeBihan, J. (2003). Critical Theory and Practice: A Coursebook. (Repr. Ed). London $\&$ New York: Routledge.

Hendricks, W. O. (1981). Review article Open and closed texts. Semiotica, 35(314), 361-379.

Jauß, H. R. (1979). Literaturgeschichte als Provokation der Literaturwissenschaft. In R. Warnin (Ed.), Rezeptionsästhetik (pp. 126-162). München: Fink München.

Jauss, H. R. (1982). Aesthetic Experience and Literary Hermeneutics. Minneapolis: University of Minnesota Press.

Kasavin, T. I. (2006). Special Theories and Philosophical Problems of Discource. Human Being, 6, 1-21.

Kosikov, G. K. (2000). 'Struktura' i/ ili 'tekst' (strategii sovremennoy semiotiki). In W. D. Mazo (Ed.), Frantsuzskaya semiotika: ot strukturalizma $k$ poststrukturalizmu (ss. 3-48). Moscow: Progress, 2000.

Kostyukovich, Ye. A. (1982). Umberto Eko: Imya rozy. Inostrannaya literatura, 5.

Makarov, M. L. (2003). Osnovy teorii diskursa. Moscow: ITDGC 'Gnosis'.

Mankovskaya, N. B. (2000). Estetika postmodernizma. St. Petersburg: Aleteya.

Paul, C. (2003). Digital Art. London: Thames and Hudson.

Pisanty, V. (2015). From the model reader to the limits of interpretation. Semiotica, 2015(206), 37-61. DOI: https://doi.org/10.1515/sem-2015-0014

Ryzhenkova, G. (2003). Umberto Eko v perevodakh Yeleny Kostyukovich. Retrieved from https://www.proza.ru/2003/01/03-99_01 September 2020.

Schmid, W. (2013). Implied reader. The living handbook of narratology. Interdisciplinary Center for Narratology. Hamburg: Hamburg University Press.

Scolari, C. A. (2009). Mapping conversations about New Media: the theoretical field of digital communication. New Media \& Society, 11(6), 943-964. https://doi.org/10.1177/1461444809336513

Slabukho, S. I. (2006). Author, Text and Reader in the Post-modern Paradigm of Intertextual Interpretation. Philosophical Sciences, 12, 78-87.

Staiger, J. (1992). Interpreting Films. Studies in the Historical Reception of American Cinema. Princeton \& New Jersey: Princeton University Press.

Tapscott, D. (1995). The digital economy: Promise and peril in the age of networked intelligence. New York: McGraw-Hill.

Toffler, A. (1980). The third wave. New York: Bantam Books.

Tolstoy, S. L. (1939). Ob otrazhenii zhizni v 'Anne Kareninoy.' Iz vospominaniy S. L. Tolstogo. Literaturnoye naslediye. Retrieved from http://tolstoy-lit.ru/tolstoy/kritika-otolstom/tolstoj-ob-otrazhenii-zhizni-v-anne-kareninoj.htm 01 September 2020.

Tulchinsky, G. L. (2001). Svoboda i smysl. Novyy sdvig gumanitarnoy paradigmy. (Rossiyskiye issledovaniya $v$ gumanitarnykh naukakh). Lewiston-Queenston-Lampeter: The Edwin Mellen Press.

Turysheva, O. N. (2010). 'Real'nyy' chitatel' kak ob'yekt literaturnoy nauki. Herald of Chelyabinsk State Pedagogical University, 10, 306-317.

Usmanova, A. R. (2000). Umberto Eko: paradoksy interpretatsii. Minsk: Propilei. 